\title{
Contribution of Housewives to Increase the Immunity of Family Members During Covid-19 Pandemic
}

\author{
Dwi A. Rahayu ${ }^{1,{ }^{*}}$ Reni Ambarwati ${ }^{1}$ Rinie P. Puspitawati ${ }^{1}$ Isnawati ${ }^{1}$ Nur Kuswanti ${ }^{1}$ \\ ${ }^{1}$ Faculty of Mathematic and Natural Sciences, Universitas Negeri Surabaya, Surabaya, Indonesia \\ *Corresponding author. Email: dwirahayu@unesa.ac.id
}

\begin{abstract}
Currently we are battling with the outbreak of a new type of infectious disease known as coronavirus disease 2019 (COVID-19). This virus causes severe acute respiratory coronavirus 2 syndrome (SARS-CoV-2). The spread of SARS$\mathrm{CoV}-2$ from human to human becomes the main transmission source; hence the rate of transmission becomes uncontrolled. One effort to prevent the infection of Covid-19 is to increase and maintain the body immunity. The purpose of this study was to describe the efforts of housewives in Indonesia to improve the immunity of family members during the pandemic of Covid-19. Data was collected through online questionnaires using Google Form distributed to the public. The respondents of this study were 170 housewives from several regions in Indonesia. Data were analyzed descriptive-quantitatively. The result revealed that housewives attempt to increase and maintain the immunity of the family members by various efforts. Vast majority (70\%) of respondents mentioned that they were preparing fresh vegetables and fruits for the family. They were also preparing high-protein foods and providing vitamins and supplements as stated by $56.9 \%$ and $57.5 \%$ of respondents respectively. The interesting finding was half of respondents (52.5\%) making herbal drinking (known as jamu) for their family. This herbs drinking was made from Indonesian plants, such as turmeric, curcuma, ginger, lemongrass, lime, etc. It was only a few of housewives (7.8\%) who did not do special effort for their family. It can be concluded that housewives have contribution to maintain the good immunity of family members as an effort to survive during the pandemic Covid-19.
\end{abstract}

Keywords: Covid-19, Herbal Drinking, Jamu, Immunity, Housewives' Participation

\section{INTRODUCTION}

In early 2020 , the world was shocked by the outbreak of a new type of infectious disease originating from Wuhan, Hubei Province, China. This infectious disease is caused by a new type of virus that has been detected from the Coronaviridae family which is thought to have originated from bats and pangolins. The World Health Organization has named the type of infectious virus the coronavirus disease 2019 (COVID-19) [1], [2], [3]. Coronavirus disease 2019 (Covid-19) is a novel highly contagious infection caused by SARS-CoV-2, which has been became a global public health challenge. This virus causes severe acute respiratory coronavirus 2 syndrome (SARS-CoV-2). The spread of SARS-CoV-2 from human to human becomes the main transmission source; hence the rate of transmission becomes uncontrolled.

The rapid spread of the Covid-19 caused many deaths in various countries and unrest of the world community. Until now, no vaccine/drug has been found to cure patients infected with Covid-19. Specific prevention of Covid-19 is necessary according to the WHO Health Protocol. One of the efforts to reduce the fluctuation rate of Covid-19 infection is to increase and maintain body immunity. Efforts to maintain body immunity can help prevent viral infections. The body's immunity must be well maintained so that it is not susceptible to Covid-19 infection. A good immune system can protect itself from the first time the virus that causes disease enters the body.

There have been multiple attempts made to ward off this Covid-19, one of which was taking multivitamins or supplements to enhance immunity [4], [5],[6]. One effort to prevent the infection of Covid-19 is to increase and maintain the body immunity. One of them is maintaining a balanced diet with nutrition as in this Indonesia. Some people consume empon-empon as multivitamins consumption to prevent Coronavirus disease. There are several ways to activate the body's immune system. Local knowledge regarding traditional health efforts is carried out through herbal traditional medicine which is passed 
down from generation to generation, through oral and written traditions. The efforts to maintain health and maintain body immunity by consuming herbal drinking should be done consistently every day to get optimal results. There are several herbs that have been studied both in vitro (in cells) and in vivo in test animals that can boost the body's immunity [6], [7], [8], [9].

Housewives are at the forefront of the battling against the pandemic Covid-19, exposing them to greater risk of infection, while they are under-represented in leadership and decision-making processes in the health care and boost the immune system for families in their home. OECD [10] stated that housewives face compounding burdens: they are over-represented working in health systems, continue to do the majority to increases the immunity of their families.

\section{METHOD}

\subsection{Participant of This Study}

This research used descriptive study. Data was collected through online questionnaires using Google Form distributed to the public. The respondents of this study were 170 housewives from several regions in Indonesia.

\subsection{Data Collection Instrument}

This study was descriptive, using a cross sectional survey of the housewives in their lived and teenage girls in Indonesia. Data were collected through an indirect online questionnaire using Google Form from Mei 10 20, 2020. These questionnaires, using closed questions and multiple-choice, essay and were distributed for Indonesia people but only answered by 170 respondents in 5 provinces.

The variables of this study were knowledge and behavior, and for each variable as one of the immunity families control strategies for housewives and teenage girls to manage their immunity in pandemic covid-19. This questionnaire was held online to the housewives' public people. We develop a questionnaire to explore the effort the housewives improving immune systems for their families. All of participants, especially teenage girls and housewives to fill out a questionnaire based on habits. By accomplishing this questionnaire, the teenage girls and housewives expected to learn about their habits for boost family immunity. The instrument used was a mixed questionnaire model with questions combined to explore the experiences of housewives and teenage girls before and during the pandemic, which is preparing immunity needs for families.

\subsection{Data Analysis}

The perception of participants as well as their responses was analyzed descriptive- quantitatively. Data were analyzed with descriptive analysis by calculating the frequency and percentage. The respondents provided information on age, educational level, occupation and mailing address. The questionnaires were purposed as a self- managed questionnaire, according to effort housewives to improve their family's immune.

\section{RESULTS AND DISCUSSION}

Currently we are battling with the outbreak of a Covid-19. The spread of SARS-CoV-2 from human to human becomes the main transmission source; hence the rate of transmission becomes uncontrolled. One effort to prevent the infection of Covid-19 is to increase and maintain the body immunity. Prevent and maintains the immunity is one of the strategies recommended to reduce the risk of morbidity and mortality caused by COVID- 19 . There have been multiple attempts made to ward off this virus, one of which was taking multivitamins or supplements to enhance immunity in family members.

The study was collected 178 questionnaires filled out online using Google Form. After filtering, the data obtained from only 170 questionnaires could be processed. Respondent came from five provinces. Most of them $(88 \%)$ were from East Java Province. As many as $31,76 \%$ of the respondents were students/bachelor graduates/unemployed, and 20\% worked as Ecopreneur, while $8,24 \%$ as housewife. The socio- demographic characteristics of the respondents are shown in Table I. This study was used online questionnaires using google form, so it only rapid respondents who have access to technology and understand how to fill out questionnaires online based on their experience.

The result revealed that housewives attempt to increase and maintain the immunity of the family members by various efforts. There are preparing fresh fruits and vegetables, providing multivitamins and supplements, making herbal drinking or Jamu, and preparing high-protein diets, while $7.8 \%$ of respondents choose no special effort, as usual. The vast majority (70\%) of respondents mentioned that they were preparing fresh vegetables and fruits for the family. They were also preparing high-protein foods and providing vitamins and supplements as stated by $56.9 \%$ and $57.5 \%$ of respondents respectively. The interesting finding was half of respondents $(52.5 \%)$ making herbal drinking (known as jamu) for their family (Fig. 1). Hence, all participants require knowledge and behavior to prevent their families during Covid-19 pandemic. Some previous research consuming supplements, vitamins, and nutrition to prevent their immunity [4]-[7], [9]. 
Table 1. Respondents' socio demographic characteristics

\begin{tabular}{|c|c|c|}
\hline Category & $\begin{array}{l}\text { Frequency } \\
\text { (n) }\end{array}$ & $\begin{array}{l}\text { Percentage } \\
\text { (\%) }\end{array}$ \\
\hline \multicolumn{3}{|l|}{ Age Range } \\
\hline 22-35 years old & 119 & 70 \\
\hline $36-50$ years old & 37 & 21,76 \\
\hline $\begin{array}{l}\text { More than } 51 \text { years } \\
\text { old }\end{array}$ & 9 & 5,29 \\
\hline \multicolumn{3}{|l|}{ Occupation } \\
\hline Housewives & 20 & 11,76 \\
\hline Entrepreneurs & 34 & 20 \\
\hline Unemployed & 54 & 31,76 \\
\hline Teachers & 62 & 36,47 \\
\hline \multicolumn{3}{|l|}{ Province } \\
\hline East Java & 150 & 88,23 \\
\hline Yogyakarta & 6 & 3,52 \\
\hline Banten & 2 & 1,17 \\
\hline North Kalimantan & 10 & 5,88 \\
\hline East Kalimantan & 2 & 1,17 \\
\hline
\end{tabular}

Herbal drinking was made from Indonesian plants, such as turmeric, curcuma, ginger, lemongrass, lime, galangal, citrus, etc. It was only a few of housewives (7.8\%) (Figure 1) who did not do special effort for their family. Herbal drinking (Jamu) is a traditional Indonesian herbal drink that is known for its anti-inflammatory properties and immune-boosting benefits. This finding interesting showed that vast majority of housewives as participants developing effort to protect their family for Covid-19 infection. There are several herbs that have been studied both in vitro (in cells) and in vivo in test animals that can boost the body's immunity, such as curcuma [7] and citrus [8].

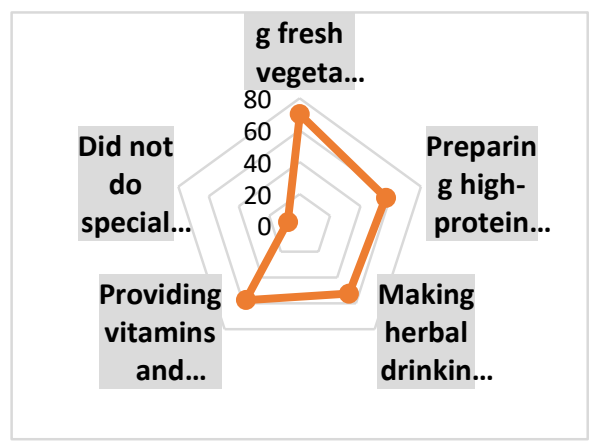

Figure 1 The perception of housewives attempts to increase and maintain the immunity of the family members by various efforts
Until now, no vaccine/drug has been found to cure patients infected by Covid-19. Specific prevention of Covid-19 is necessary according to the WHO Health Protocol. One of the efforts to reduce the fluctuation rate of Covid-19 infection is to increase and maintain body immunity. The efforts to maintain body immunity can help prevent viral infections. The body's immunity must be well maintained so that it is not susceptible to Covid19 infection. A good immune system can protect itself from the first time the virus that causes disease enters the body.

As shown in Table 2, all of the participants (64,705\%) which is know that turmeric and kaffir lime as a benefit to maintaining immunity, but $(60,58 \%)$, they do not know the benefits and processing it into herbal drinking. Turmeric and kaffir lime contain substances that increase the activity of the immune system, namely vitamin $\mathrm{C}$ and secondary metabolites, and will function if consumed. It will be easier if consume both of plant herbs. In this case, the use of turmeric and kaffir lime can be consumed in the form of a fresh drink, as well as to activate the immune system [11].

This finding interesting showed that, some of the herbal plants used by the community are turmeric, ginger, galangal, lemongrass, lime, kaffir lime, lemon, cardamom, secang, cloves and temu ireng. The community processes these herbal plants by boiling them directly; squeezed out; thinly sliced then brewed; brewed with warm water. However, there is no special processing related to the herbal ingredients consumed by housewives and teenagers' girls in their home. Besides, the difficulties faced by the community in the addition of herbal ingredients are the relatively long preparation time and relatively short shelf life of the ingredients, so they have to make them every day.

Local knowledge about traditional herbal drinking is carried out through herbal traditional medicine which is passed down from generation to generation, through oral and written traditions. Housewives have a significant contribution to maintaining the good immunity of family members as an effort to survive during the pandemic Covid-19. More than half of the participants $(47,05 \%)$ recommended have been able to make instant herbal drinking later if there is a desire for entrepreneurship. 
Table 2. Results of responses to questionnaire distribution

\begin{tabular}{|c|c|c|c|}
\hline Instruments & $\begin{array}{l}\text { Respons } \\
\mathrm{e}\end{array}$ & $\begin{array}{l}\text { Frequenc } \\
\text { y (n) }\end{array}$ & $\begin{array}{l}\text { Percentag } \\
\text { es (\%) }\end{array}$ \\
\hline \multirow{2}{*}{$\begin{array}{lr}\text { Have you } & \text { ever } \\
\text { making } & \text { herbal } \\
\text { drinking } & \text { from } \\
\text { turmeric } & \text { and } \\
\text { lime? } & \end{array}$} & $\begin{array}{l}\text { never } \\
\text { before }\end{array}$ & 103 & 60,58824 \\
\hline & ever & 67 & 39,41176 \\
\hline \multirow{2}{*}{$\begin{array}{l}\text { Do you know the } \\
\text { benefits of turmeric } \\
\text { as an immune } \\
\text { booster? }\end{array}$} & know & 110 & 64,70588 \\
\hline & $\begin{array}{l}\text { Do not } \\
\text { know }\end{array}$ & 60 & 35,29412 \\
\hline \multirow{3}{*}{$\begin{array}{l}\text { Did you often make } \\
\text { turmeric herbal } \\
\text { drinking during the } \\
\text { Covid } 19 \text { Pandemic? }\end{array}$} & rarely & 63 & 37,05882 \\
\hline & often & 99 & 58,23529 \\
\hline & never & 8 & 4,705882 \\
\hline \multirow{2}{*}{$\begin{array}{l}\text { Did you often make } \\
\text { kaffir lime drinking } \\
\text { during the Covid } 19 \\
\text { Pandemic? }\end{array}$} & ever & 169 & 99,41176 \\
\hline & never & 1 & 0,588235 \\
\hline \multirow{3}{*}{$\begin{array}{l}\text { Are you interested in } \\
\text { making herbal } \\
\text { drinking to increase } \\
\text { body immunity }\end{array}$} & $\begin{array}{l}\text { not } \\
\text { interested }\end{array}$ & 6 & 3,529412 \\
\hline & sometimes & 1 & 0,588235 \\
\hline & interested & 163 & 95,88235 \\
\hline \multirow{3}{*}{$\begin{array}{l}\text { Have you able to } \\
\text { make an instant herbal } \\
\text { drinking later, if there } \\
\text { is a desire for you for } \\
\text { entrepreneurship? }\end{array}$} & yes & 80 & 47,05882 \\
\hline & $\begin{array}{l}\text { Yes, but not } \\
\text { anytime } \\
\text { soon }\end{array}$ & 70 & 41,17647 \\
\hline & No & 20 & 11,76471 \\
\hline
\end{tabular}

\section{CONCLUSION}

It can be concluded that housewives have contribution to maintain the good immunity of family members as an effort to survive during the pandemic Covid-19. We suggest that this routine effort to protect their family could inhibit the infection of Covid-19 in Indonesia, and, thus, the pandemic will be rapidly brought under control.

\section{ACKNOWLEDGMENTS}

Thanks to all correspondents who have filled out the questionnaire properly and honestly from his experience in maintaining family health conditions amid the covid19 pandemic.

\section{REFERENCES}

[1] F. Di Gennaro et al., "Coronavirus diseases (COVID-19) current status and future perspectives: A narrative review," Int. J. Environ. Res. Public Health, vol. 17, no. 8, 2020, doi: 10.3390/ijerph17082690.
[2] H. G. W. M. Shah, B. Ahmad, S. Choi, "Infectivity, Sequence variation of SARS-CoV-2 spike protein may facilitate stronger interaction with ACE2 promoting high infectivity," Preprint, pp. 1-21, 2020, doi: 10.21203/rs.3.rs-16932/v1.

[3] R. Yan, Y. Zhang, Y. Li, L. Xia, Y. Guo, and Q. Zhou, "Structural basis for the recognition of SARSCoV-2 by full-length human ACE2," Science (80-. ), vol. 367, no. 6485, pp. 1444-1448, 2020, doi: 10.1126/science.abb2762.

[4] A. Saghazadeh and N. Rezaei, "Immuneepidemiological parameters of the novel coronavirus-a perspective," Expert Rev. Clin. Immunol., vol. 16, no. 5, pp. 465-470, 2020, doi: 10.1080/1744666X.2020.1750954.

[5] F. Aman and S. Masood, "How nutrition can help to fight against covid-19 pandemic," Pakistan J. Med. Sci., vol. 36, no. COVID19-S4, pp. 121-123, 2020, doi: 10.12669/pjms.36.COVID19-S4.2776.

[6] M. F. Aslam, S. Majeed, S. Aslam, and J. A. Irfan, "Vitamins: Key role players in boosting up immune response-a mini review," Vitam. Miner., vol. 06, no. 01, pp. 1-8, 2017, doi: 10.4172/23761318.1000153.

[7] N. Boroumand, S. Samarghandian, and S. I. Hashemy, "Immunomodulatory, anti-inflammatory, and antioxidant effects of curcumin," J. Herb. Med. Pharmacol., vol. 7, no. 4, pp. 211-219, 2018, doi: 10.15171/jhp.2018.33.

[8] R. F. Najwa and A. Azrina, "Comparison of vitamin $\mathrm{C}$ content in citrus fruits by titration and high performance liquid chromatography (HPLC) methods," Int. Food Res. J., vol. 24, no. 2, pp. 726$733,2017$.

[9] S. Khodadadi, "Role of herbal medicine in boosting immune system," Immunopathol. Persa., vol. 1, no. 1, p. 1, 2015, [Online]. Available: http://www.immunopathol.com.

[10] O. for E. C. and D. (OECD), "Women at the core of the fight against COVID-19 crisis," p. 30, 2020, doi: 10.1787/92c0ef68-en.

[11] R. M. W. Purwanto, J. Pabontong, E. S. Retnoningtyas, and W. Irawaty, "Antimicrobial Activity of Kaffir Lime Peel Extract against Streptococcus mutans," Reaktor, vol. 18, no. 4, pp. 235-240, 2018. 